
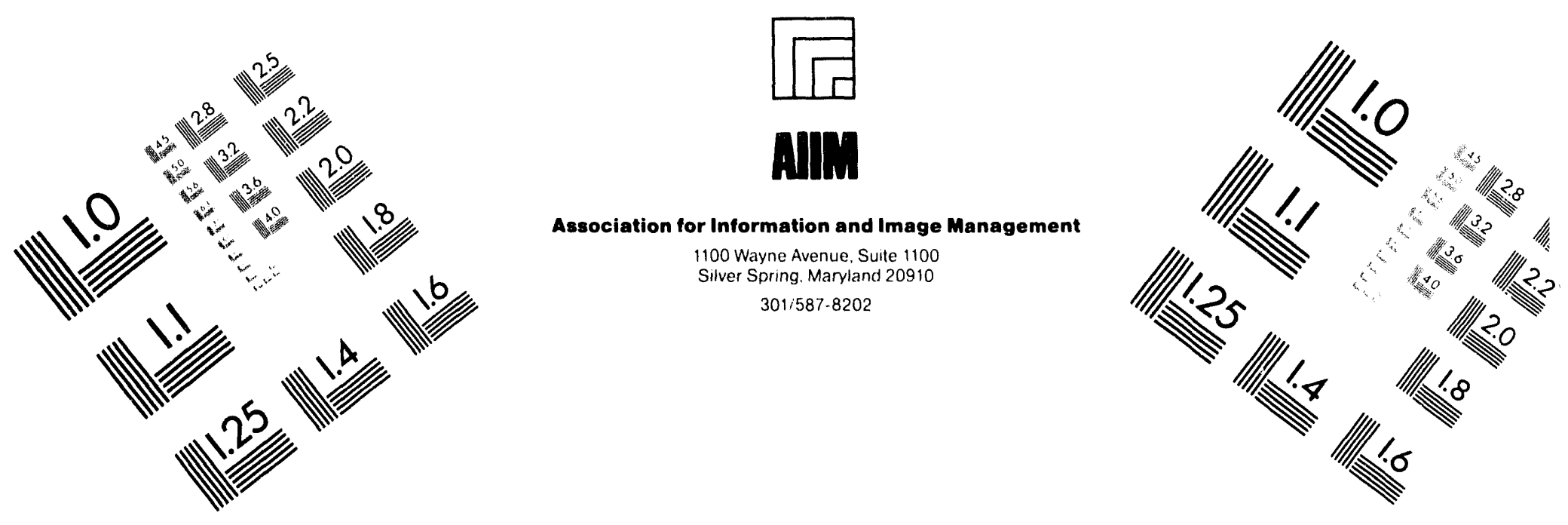

\title{
Centimeter
}

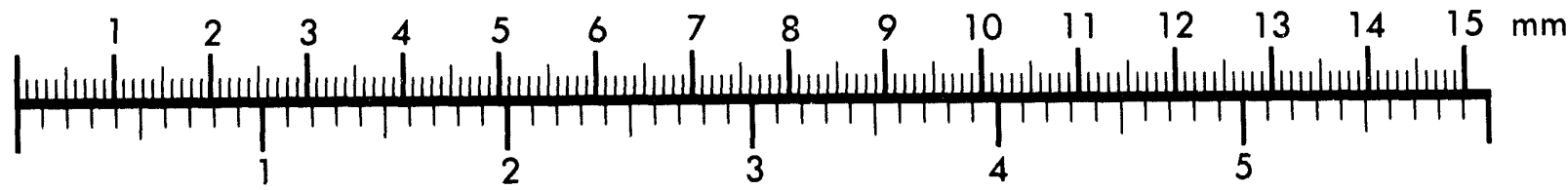

Inches
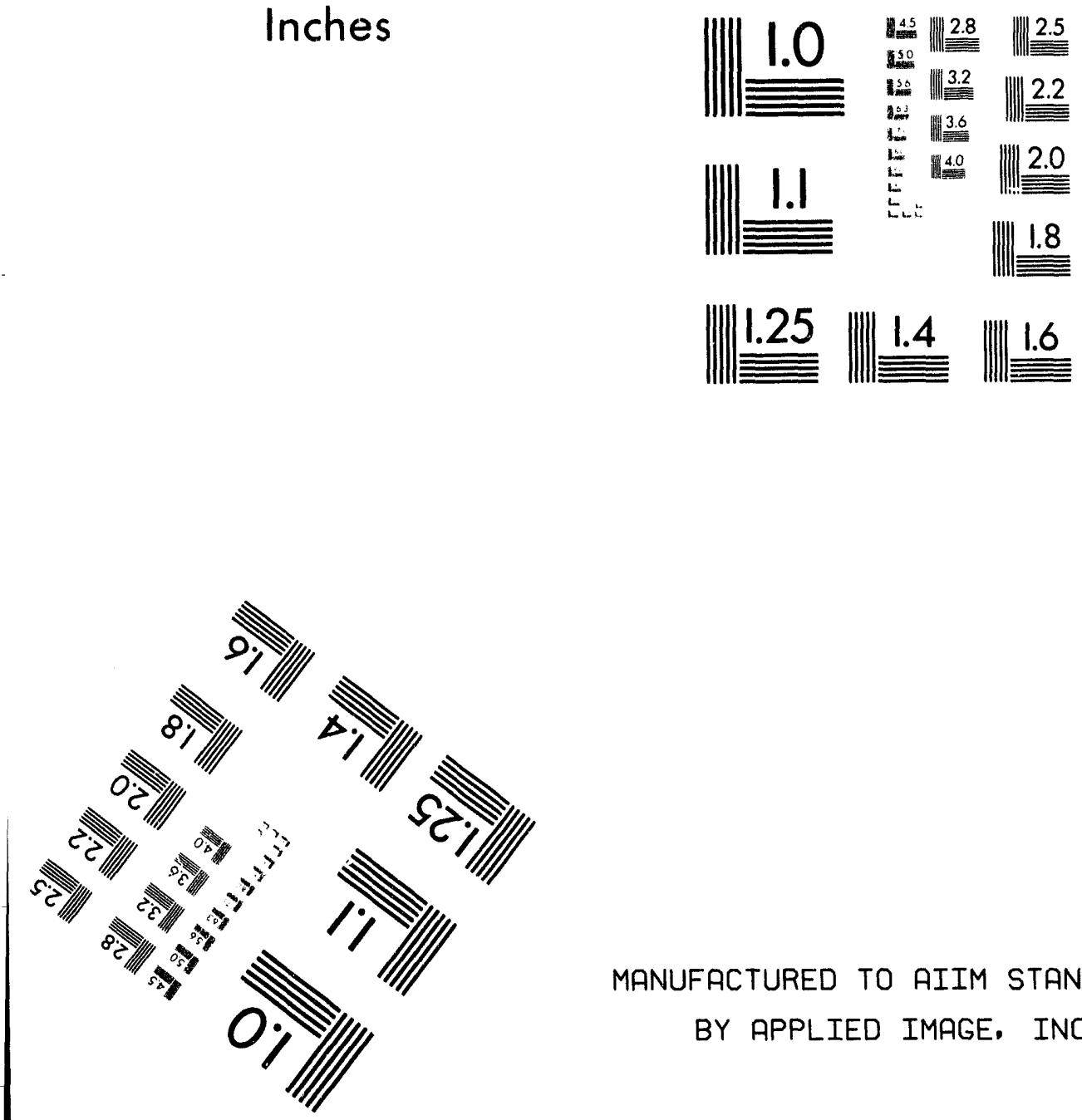

MANUFACTURED TO AIIM STANDARDS

BY APPLIED IMAGE, INC.

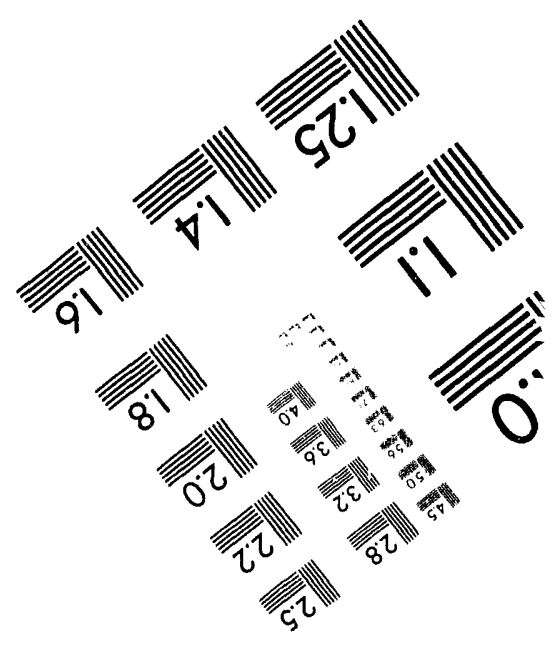



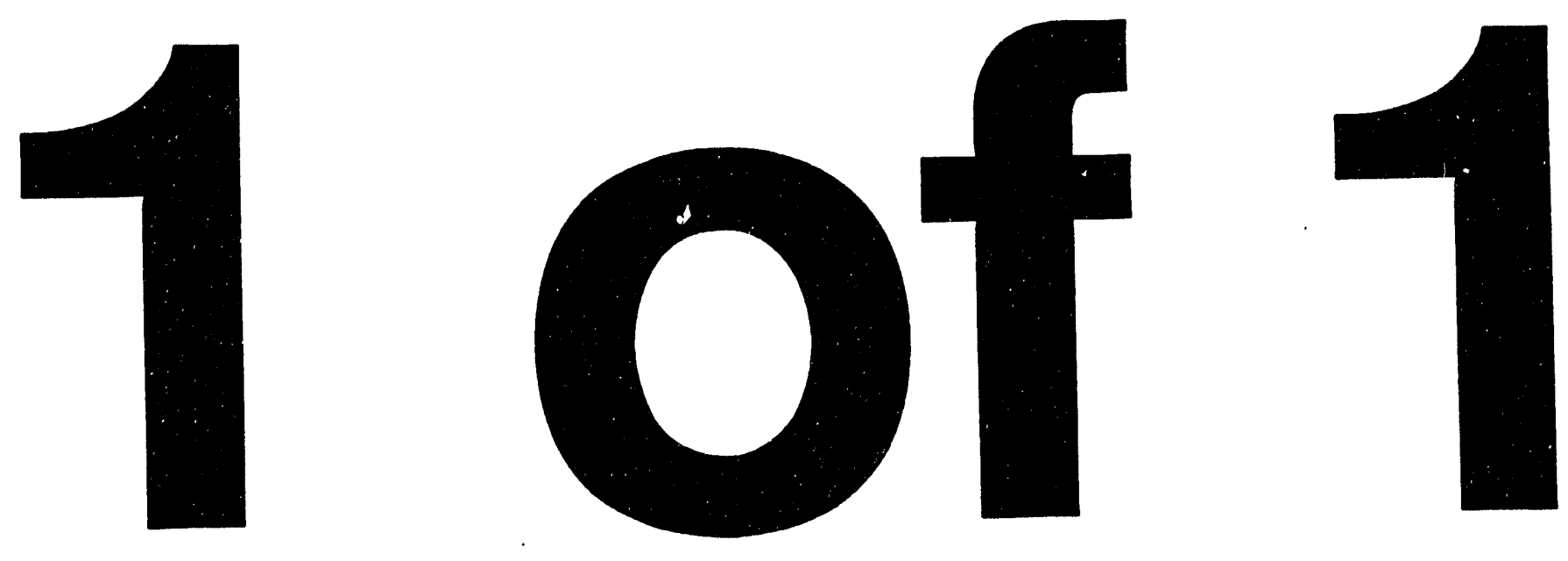


\section{GENERAL (gRTECTRIC}

HANFORD ATOMIC PRODUCTE OPERATION - RICHLAND, WABHINGTON

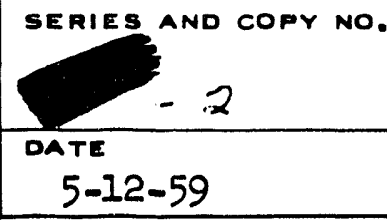

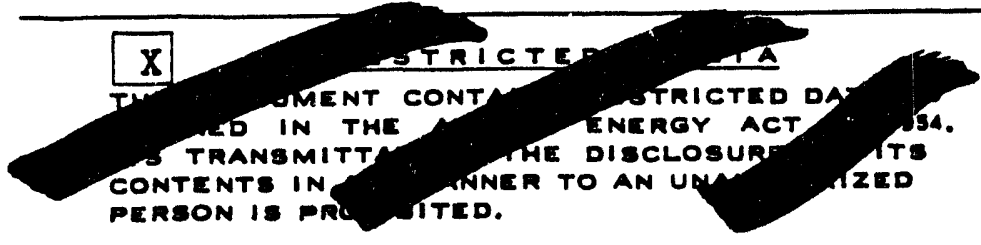

OTHER OFFICIAL CLABEIFIEO INFORMATION

THIS MATERIAL CONTAINS INFORMATION AFFECTING THE NATIONAL DEFENBE OF THE UNITED STATES WITHIN THE MEANING OF THE ESPIONAGE LAWB. TITLE 18, U.S.C., BECS. TOS AND TOA, THE TRANBMISEION OR REVELATION OF WHICH IN ANY MANNER TO AN UNAUTHORIZED PERSON IS PROHIDITED DY

LAW.

THIS DOO MUST NOT DE LEFT UNAT- ON WHERE AN UNAY

To 17 G). - AREA. WHILE it is IFIED FILE o IT I8

IS PROJECT AND FRO

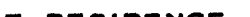

OF RESIDENCE IS OBTAIN THEM NTED. IT IS NOT TO UEBBION AND UNTU

PHISICS AND INSTRUMIENT RESEARCH AND DEVIHLOPMIIT OPERATION - MONTHLY REPORT APRII 1959

\section{AUTMOR}

P. F. GAST

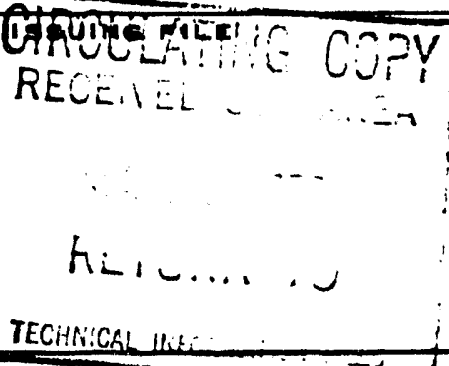
AND ITE CONTENTS WIT
TRANEMITTAL TO, AND g UPLICATED. IF ADDITION ALL BERBons nEADING THM Ne CIMITS OF
AT rOUR PLACE PIES ARE REQUIRED, UMENT ARE REQUESTED

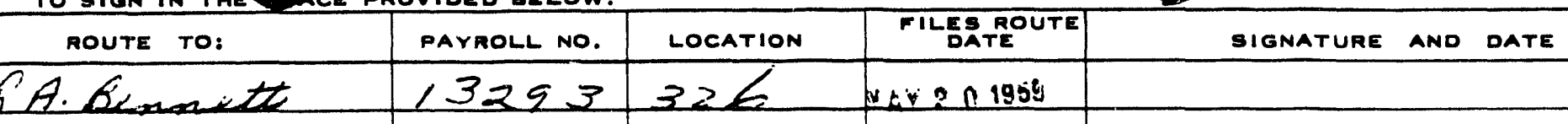


This document consists

of 28 pages. Copy No.

of 64 copies.

PHISICS AND INSTYRUWMTI RESEARCH AND DEVELOPMENT OPERATION

MONTHII REPORT

APRII 1959

DECLLSSFFIED

\author{
Compiled by Members' of the \\ PHISICS AID INSTRUMIITI RESEARCH AND DEVELOPMENTT OPERATION \\ HAITFORD IABORATORIES OPERATION
}

Submt.tted by: P. F. Cast

May 12, 1959

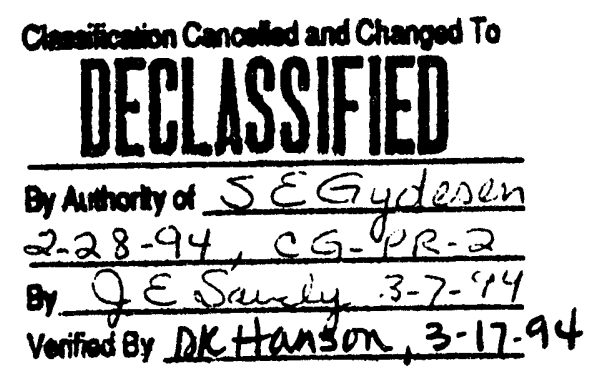

Operated for the Atomic Energy Commission by the

General Electric Company under Contract $\# w-31-109-E n g-52$

\title{
haNFORd ATOMIC PRODUCTS OPERATION RICHLAND, WASHINGTON
}

\section{PRELIMINARY REPORT}

"This report was prepared only for use within General Electric Company in the course of work under Atomic Energy Commission Contract W-31-109-Eng-52. Any views or opinions expressed in the report are those of the authors only."

\section{LEGAL NOTICE}

onsored work. Neither the United States, This report was prepared as an account of Government sponsored
nor the Commission, nor any person acting on behalf of the Commission:

A. Makes any warranty or representation, express or implied, with respect to the accuracy, completeness, or usefulness of the information contained in this report, or that the use of any information, apparatus, method, or process disclosed in this report may not infringe privately owned rights; or

B. Assumes any liabilities with respect to the use of, or for damages resulting from the use of any information, apparatus, method, or process disclosed in this report.

As used in the above, "person acting on behalf of the Commission" includes any employee or contractor of the Commission to the extent that such employee or contractor propares, handles or distributes, or provides access to, any information pursuant to his employment or contract with the Commission.

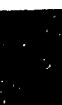

(1)
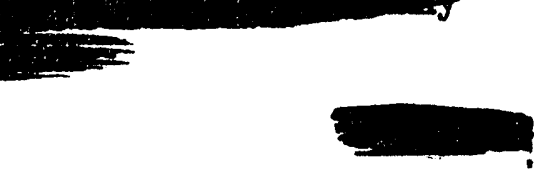
1. ER Astley

2. RA Bennett

3. EZ Block

4. AB Carson

5. J Carter

6. BC Clark

7. ED Clayton

8. VR Cooper

9. RL Dickeman

10. GWR Endres

11. FC Engesser

12. JE Faulkner

13. WC Finch

14. DG Foster

15. HA Fowler

16. WJ Friesen

17. SJ Frlesenhahn

18. RM Fryar

19. AC Fullmer

20. PF Cast

21. OH Greager

22. RA Harvey

23. RE Heineman

24. III Henry

25. OF Hill

26. GR Hilst

27. AR Keene

28. II Ketzlach

29. HA rormbers

30. DA Kottwitz

31. CR Lagergren

32. BR Leonard
33. JR ItIley

34. RC Lloyd

35. DD Matsumoto

36. JH McCrary

37. VI Neeley

38. PF Nichols

39. $R$ Nilson

40. TJ Dakes

41. WC Roesch

42. JT Russell

43. JE Schlosser

44. IC schmid

45. DS Selengut

46. RB Smith

47. RE Smith - CL Brown

48. RI Smith

49. RI Stevenson

50. WP Stinson

51. JI Stringer

52. JW Talbott

53. RE Tomlinson

54. JR Triplett

55. DE Wood

56. JR Worden

57. 300 Files

58. Record Copy

59-60. Extra Copies

61. HOO-AEC - Att: JT Chrlsty

62. HOO-AEC - Att: HA House

63. HOO-AEC - Att: JM Musser

64. HOO-AEC - Att: HH Schipper 
PHISICS AND INSTRUMEHVT RESEARCH AND DEVELOPMENT OPERATION

\section{MONTHEY REPPORT}

APRII 1959

\section{FISSIOAIABIS MATERTAIS - 2000 PROGRAM}

\section{FUELS}

Nuclear Safety in the Fuels Preparation Department

A meeting was held with members of the Puels Preparation Department to discuss nuclear safety criteria for the design and operation of a co-extrusion plant for the manufacture of ITR fuel elements. The Fuels Preparation Department are now making a study of these criterla and will submit detalled processIng requirements at a later date so that the nuclear safety of the process can be analyzed.

Nuclear safety in the co-extrusion of 1.6 percent U-235 enriched uranium was also discussed. Operating procedures have been submitted and will be analyzed for nuclear safety. The project involves the manufacture of 3.5-inch diameter billets at Fernald. These billets are then to be shipped to Hanford for cladding in Zircaloy-2 and copper tubing. They will then be shipped in wooden boxes to Nuclear Metals, Inc., where the billets will be coated with a graphite slurry, heated to $1150-1200 \%$ and then extruded into long tubes of 0.580. Inch diameter. The rods will then be cut to about 17-foot lengths, put in wooden boxes and shipped back to Hanford.

\section{REACTOR}

STUDIES REIATFD TO PRESEITT PRODUCTION REACTORS

\section{Lattice Neutron Temperature Study}

The first part of this study has been completed and is reported in the January, February, Narch Nuclear Physics Research Quarterly Report.

\section{Thermal Neutron Flux Spectrum Near a Temperature Discontinuity}

The IBM 709 FORTRAN program to obtain numerical results for the analytic solutions to the temperature discontinuity problem has been debugged and checked on two simple cases. Thls program will perform calculations in all three of the Infinite geometries for which analytic solutions have been found--plane, slab, and cylindrical. Although the basic program operated satisfactorily on the check cases, the desirability of several changes, princlpally in input and output features, has been revealed.

\section{Neutron Energy Spectrum Near a Temperature Discontinuity}

The theoretical analysis of the experimental work has been completed on neutron exchange between equilibrium thermal neutron energy distributions near a temperature discontinuity in graphite. The results are at present anly in graphic 
form and final evaluation of the precision of the results is not available yet.

Instrumentation

The input address logic and core drive units of the simple computer, using magnetic cores has been tested and debugged. This unft works satisfactorily and only few changes and improvements are foreseen. Work is continuing on the development of core readout reglster drives and arlthmetic units along with inhibit drives for write-in.

The stack effluen. gas monitor for the 100-D stack was lnstalled and was operated for two weeks. The detector is a NaI crystal and phototube in a 10-Inch diameter hollow aluminum sphere. Gas flow through the sphere is two to three CFM. Several satisfactory spectrum analyses (gamma energy) have been obtained. Viewing only the photopeak portion of II3I, the original count contribution was about $250 \mathrm{c} / \mathrm{m}$. After two weeks of operation, this level is now up to about $375 \mathrm{c} / \mathrm{m}$ indicating alight contamination within the sphere. None of the ganma enersy spectrum analysis dats have shown any clearly discernible energy peaks to date. However, we are waiting for a slus mupture to occur to provide us with better data. Some 110 VAC IIne transient and stack bouse heat problems have occurred indicating that the counting equipment should be changed to another butlding if possible. The air temperature in the 105-D stack house was between $110^{\circ} \mathrm{F}$ and $120^{\circ} \mathrm{F}$ on April 22, 1959.

A complete five-probe scintillation monitoring and alarm system was designed for the 100 Areas for use on the elevators. The system incorporates five probes cable-connected to the main indicating and recording instrument. Any range can be covered, by high-voltage changes, from a flrst range of $0-10 \mathrm{mr} / \mathrm{hr}$ up to 0-10 r/hr. Two-inch by two-inch terphenyl-in-polyvinyltoluene detectors are used giving an approximately gam energy independent system above $90 \mathrm{Kev}$. Each probe has an Indfcating meter and alarm light and the central station comprises five indicating alarming meter relays and a recorder. The remote probes are set up to be elther bracket-mounted on the elevator or hand-held for close work. The incorporated probe meter continuously tells the individual holding the probe what the dose rate 1s. All range switching is done at the control or central station.

\section{STUDTES RETALED TO FUIURE PRODUCMION RMACTORS}

Lattice Messurements for Large Diameter Fuel Elements

The exponential pile program of measurements on lattices using 1.92-inch and 2.5-1nch solid fuel elements is now nearing completion.

The material bucklings listed in Table I have been measured this month. Note should be taken that one lattice has a tube and tube fuel assembly. The program now involves the simultaneous measurement of bucklings in two exponential piles. 


\section{TABIE I}

Fuel

Element

2.50 Inch solid

1.92 Inch solid

\section{$2.5 \times 2.0$ with}

$1.66 \times 1.1$
Lattice

Spacing

$149 / 16$ Dry

$123 / 8$ Dry

$149 / 16$ Dry
Buckling

$\left(10^{-6} \mathrm{~cm}^{-2}\right)$

$+92$

$+108$

$+57$
Volume Ratios

$\frac{\overline{A I / U}}{0.185} \quad \frac{\mathrm{H}_{2} \mathrm{O} / \mathrm{U}}{-.} \frac{\mathrm{C} / \mathrm{U}}{41.58}$

0.264

51.31

68.46

These buckling values are tentative using an estimated side extrapolation distance, $\lambda$, of 1.66 inches and a front to rear extrapolation distance of 1.03 inches. Horizontal traverses have been taken to determine the actual $\lambda$.

Analysis of several horizontal traverses involving 1.92-inch and 2.50-inch fuel elements has been completed. Final bucklings are shown in Table II. The same front-to-rear $\lambda$ of 1.03 inches has been used for each lattice. The values of $\lambda$ tabulated seem to have rather large deviations from pile to pile, although the measurements were made with care.

\section{TABIE II}

\section{FITAL BUCKLIITG VALUES}

\begin{tabular}{|c|c|c|c|c|c|c|}
\hline \multirow{2}{*}{$\begin{array}{l}\text { Puel } \\
\text { Element }\end{array}$} & \multirow{2}{*}{$\begin{array}{l}\text { Lattice } \\
\text { Spacing }\end{array}$} & \multirow{2}{*}{$\begin{array}{l}\text { Buckeling } \\
\left(10^{-6} \mathrm{~cm}^{-2}\right)\end{array}$} & \multirow{2}{*}{$\begin{array}{l}\text { Side to } \\
\text { Side } \lambda \\
\text { (Inches) }\end{array}$} & \multicolumn{3}{|c|}{ Volume Ratios } \\
\hline & & & & $\mathrm{A \perp} / \mathrm{U}$ & $\mathrm{H}_{2} \mathrm{O} / \mathrm{U}$ & $\mathrm{C} / \mathrm{U}$ \\
\hline $\begin{array}{l}1.92 \\
1.92\end{array}$ & $\begin{array}{lll}6 & 3 / 16 & \text { Dry } \\
6 & 3 / 16 & \text { Wet }\end{array}$ & $\begin{array}{l}-400 \\
-186\end{array}$ & $\begin{array}{l}1.20 \\
1.34\end{array}$ & $\begin{array}{l}0.264 \\
0.264\end{array}$ & $0 . \overline{288}$ & $\begin{array}{l}11.64 \\
11.64\end{array}$ \\
\hline $\begin{array}{l}1.92 \\
1.92\end{array}$ & $\begin{array}{lll}8 & 3 / 8 & \text { Dry } \\
8 & 3 / 8 \text { Wet }\end{array}$ & $\begin{array}{l}.67 \\
+65\end{array}$ & $\begin{array}{l}1.55 \\
1.55\end{array}$ & $\begin{array}{l}0.264 \\
0.264\end{array}$ & $0 . \overline{288}$ & $\begin{array}{l}22.65 \\
22.65\end{array}$ \\
\hline $\begin{array}{l}2.50 \\
2.50\end{array}$ & $\begin{array}{ll}8 & 3 / 8 \text { Dry } \\
8 & 3 / 8 \text { Wet }\end{array}$ & $\begin{array}{l}-199 \\
=60\end{array}$ & $\begin{array}{l}1.30 \\
1.55\end{array}$ & $\begin{array}{l}0.185 \\
0.185\end{array}$ & $0 . \overline{403}$ & $\begin{array}{l}12.67 \\
12.67\end{array}$ \\
\hline $\begin{array}{l}2.50 \\
2.50\end{array}$ & $\begin{array}{lll}10 & 3 / 8 & \text { Dry } \\
10 & 3 / 8 & \text { Wet }\end{array}$ & $\begin{array}{l}+88 \\
+49\end{array}$ & $\begin{array}{l}1.59 \\
1.41\end{array}$ & $\begin{array}{l}0.185 \\
0.185\end{array}$ & $0 . \overline{403}$ & $\begin{array}{l}20.31 \\
20.31\end{array}$ \\
\hline $\begin{array}{l}2.50 \\
2.50\end{array}$ & $\begin{array}{lll}12 & 3 / 8 & \text { Dry } \\
12 & 3 / 8 \text { Wet }\end{array}$ & $\begin{array}{l}+108 \\
+28\end{array}$ & $\begin{array}{l}1.68 \\
1.95\end{array}$ & $\begin{array}{l}0.185 \\
0.185\end{array}$ & $0 . \overline{403}$ & $\begin{array}{l}29.58 \\
29.58\end{array}$ \\
\hline 2.50 & $149 / 16$ Wet & -29 & 1.29 & 0.185 & 0.403 & 41.58 \\
\hline
\end{tabular}

Coordinated Theoretical - Experimental Program

The direction of previous effort in correlating theory with exponential pile data has been toward using varlous approximations in microscopic lattice theory. This approach implicitly assumes that the experimental values, as determined by 
the conventional procedure, are correct. The validity of this assumption for heterogeneous lattices, particularly in small exponential assemblies, is being examined.

Experimental work on the effect of vold channels on the diffusion area has recently been summarlzed in Power Reactor Technology 214 (1959), with the conclusion that measurements on graphite assemblies conflrm the theory of D. J. Behrens. For the case of neutrom streaming perpendicular to the channels, an alternative diffusion theory expression obtained previously (Monthly Report, May 1958) has been used to obtain the values of $\left(I_{0} / I_{0}\right)^{2}$ diffusion in the following table. The subscript o refers to the solld graphite; homogeneous refers to the case of vold dimenstons small compared to a mean free path in the graphite, so that a simple density correction is sufficient. In the expression due to Behrens, $\mathrm{r} / \lambda$ is the ratio of hydraulic diameter of the vold to graphtte mean free path, and $Q=1.33$ for a circular cross section and 1.49 for a square.

A. P. Schmitt, et al, Second Geneva Conference, A/Cone. 15/P/1191

\section{Experiment}

$\frac{\text { Experiment }}{\text { Vold Cross Section }}$
$0=\frac{\text { vold volume }}{\text { graphite volume }}$
$\left(\mathrm{L} / \mathrm{L}_{0}\right)_{\text {homogeneous }}^{2} \cdot(1+\phi)^{2}$
$\left(\mathrm{~L} / \mathrm{L}_{0}\right)_{\text {dIffusion }}^{2}=(1+\phi)(1+2 \phi)$
$\left(\mathrm{L} / \mathrm{L}_{0}\right)_{\text {Behrens }}^{2}=1+2 \phi\left(1+\frac{3}{8} \frac{\mathrm{Q}}{\lambda}\right)$
$\left(\mathrm{L} / \mathrm{L}_{0}\right)_{\text {experimentsl }}^{2}$

C1rcular, $7 \mathrm{~cm}$. diameter .106

1.223

1.340

1.353

$1.393 \div .045$
I. Seren Alls Neeting Dec. 1958

Paper 3.6

Square, 11.38 cm. sides .333

1.78 $2.22 *$ 2.33 2.26

* Calculated for a circular cross section; the actual square cross section should lead to a slightly higher value.

It should be emphasized that the agreement of the diffusion result with experiment is of questionable signiflcance since the derivation does not apply to the case of a vold region. However, it suggests that the diffusion expression may be valid over a wider range than its derlvation would indicate.

\section{IPR Lattice Measurements}

Bids have been received on the graphite to be used in the exponential pile which will be loaded with NPR fuel elements.

\section{Intercalibration of Graphite Purity}

The moderating effect correction to the PCTR graphite absorption cross section measurement is st1ll uncertain. Isotopic analyses of two samples of the $D_{2} O$ 
used in determining the correction are now available, but the results of the analyses are confusing and appear to be in error in some manner. Another $D_{2} O$ sample will be analyzed to eliminate this difflculty.

A document descrfbing this program in some detall has been prepared for publication in the open literature and will be submitted after all the results are final.

Mechanism of Graphite Damage

The measurement of the energy 1088 in thin folls required measuring a small difference between two large numbers. The stabllity of the system required for this is being checked again. An attempt is being made to measure the heat increment of the foll directly so that the difference measurement may be avolded. The Wheatstone bridge used for temperature measurement was rearranged to improve the response time at the expense of some loss in sensitivity.

\section{Computational Programs and Services}

The Exponential Data program has now been checked out and is operational. The P-3 subroutine for the IPD lattice parameter calculation program is nearly complete, the most difflcult part having been debugged.

\section{a. Least Bquares Program (I.inear Regression Only)}

The code will handle any regression problem which is reductble to linear form. For example, $y=a x^{2}+b$ is IInear if the varlable $x^{2}$ is evaluated and entered as, say, 2. Exponential regression anolysis is handled with a single "statement" of "do take logarlthms." In all cases the code will do a welghted regression analysis using specifled welghts only. The output gives constants of the Ilnear expression and their errors. One case specifies the confidence level of the solution by stating the students " $f$ " test parameter $f_{n-2,} \alpha$.

\section{b. Expos Program}

This is a special code written specifically for evaluation of a thermal activity function in the graphite core of the PCIR. It does however have wide application. The general form of the calculated expression is

$$
y=A e^{\alpha x}+B e^{b x}+C e^{b x}+D e^{\delta x}+E x^{2}+F x+G .
$$

All constants A, B, . ., $\alpha, \beta, \ldots$, etc. are to be specified and, of course, may be zero. The code evaluates the function $y$ for integral values of $x$. The range of the independent variable $x$ may be specifled.

c. IEUTHERM Program

The code was written to solve the matrix of the coefficients of the solutions to a set of four simultaneous plane diffusion equations for a two region, two thermal group problem. It calculates the thermal activity of a I/v detector in both regions, compares the calculated curve with a corresponding experimental curve polnt by point to obtain the residual sum of 
squares of the fit, and repeats the solution a specified number of times. The repeating of the solution is an iteration process on a coupling coefficlent between the original differential equations. The interval of iteration is specified initially and thereafter is reduced by a factor of 10 as necessary to obtain the mintmum resldual sum of squares or until the speclfled number of 1terations has been performed. The output is the input, the final iteration, and the flux curve or all iterations and flux curves, as specified. This code was written by R. A. Cahoon of IPD.

d. Mult1-Thermal Neutron Group Diffusion Program

Attempts have been made to develop a program capable of dealing with one fast group and two thermal groups, using a three-group program, $F_{3}(I)$, as a basis. The FORIRAN Ilsting for $\mathrm{F}_{3}$ is given in (1). Attemptis to run teat cases, using a deck as punched from the document listing have been unsuccessful, so this approach was dropped.

e. A Program for Analyzing PCIR Data

Descriptions of portions of the proposed program are being circulated to physicists using the FCTR. Subjects covered include:

1. Foll data analysis

2. Reactivity data analyais

3. Thermal absorption cross sections to be used in calculating $k_{\infty}$ and $f$.

4. Corrections for resonance absorption effects upon thermal traverses.

5. Computation of errors assoclated with all of the above.

6. Computation of the error in $k_{\infty}$ due to spectral mismatch.

The above have been written as individual subroutines. The input format In all cases has been kept as simple as possible. Remaining work involves figuring out a simple way of calculating average fluxes for the several regions in a cell and specifylng the layout of the main program which ties all the subroutines together. Virtually no actual programming has been done.

STUDIFS RRTLATHD TO SEPARATIOMTS PLAIVTS

Critical Hazards Specifications

Nuclear Safety in Hanford Laboratorles

A rough draft of general nuclear safety specifications was prepared.

Speciflcations have been issued for Critical Nass Physics governing the storage and handling of U235-Al alloy fuel elements, 1.44 percent and 1.6 percent, $U^{235}$ enriched $I$. and $E$. fuel elements, and 3.0 percent $U^{235}$ enriched fuel elements.

(1) Keppler, J. G., and Orr, W. L., "Three Group Neutron Diffusion Calculation (Program $F_{3}$-IBM 704)," XDC-58-7-18. 
At the request of the Plutonlum Metallurgy Operation, a study has been made of the nuclear safety in storage and shtpping of 7 percent Pu (by welght) - Al alloy fuels. These elements are one-inch diameter rods, five feet-two inches long. Each rod contalns about 90 grams Pu. These fuel elements are being sent by alr express to Savannah River. It was determined that an array of boxes containing a total of 168 of these elements would be safe under the following conditions:

(1) Each box would contain 12 rods spaced on four-inch centers in three rows of four rods each.

(2) The 12 rods are centered in a box whose cross section is 24 inches by 36 inches.

It is belleved that these storage and shipping criterla have a safety factor of at least two.

\section{E-Netal Program}

Two meetings were held with members of the AEC-HOO to discuss the E-Netal PrCgram, particularly the analysis made by PIRDO of the random loading of the E-Netal dissolver.

\section{AEC-HOO Nuclear Safety Consulting}

A meeting was held with a member of the Separations Branch, AEC, regarding nuclear safety in the shipment of a proposed weapon model. When a firm production schedule is made, a formal request for a nuclear safety shipping speciflcation will be made.

\section{Plutonium Critical Mass Laboratory}

Invitation for b1ds, No. AT (45-1) - 1446, for construction of the Critical Mass Laboratory Facilitiea, 200-East Area, was 1ssued by the ABC on April 8; bid opening was scheduled for Nay 6 .

At the request of the Commission a concrete block structure was substituted In lieu of the 40 x $80 \mathrm{ft}$. metal excess Army mess hall which was to have been used for the control bullding. An addendum to invitation to bid was issued asking interested bldders to bld on this basis and extending bid opening date to May 20.

Radiation Ievels for a Potential Criticality Incldent at the Hanford Critical Mass Laboratory

A detalled calculation of radiation levels at various points at the proposed Hanford Plutonium Crftical Mass Pacility has been performed based upon a maximum burst of $3 \times 1018$ fissions. The purpose of this calculation was to confirm the prediction contained in $\mathrm{HW}-57603$, dated September 30, 1958, "Preliminary Hazards Study of the Hanford Plutonium Critical Mass Laboratory," that "the reactor room walls and celling are of such thickness that the radiation dose to personnel in areas outside the reactor room to which access is permitted will be less than 100 mrem for a burst as large as $3 \times 10^{18}$ fissions." 
The $r$ radiation was divided into four energy groups. The direct doses calculated are tabulated below.

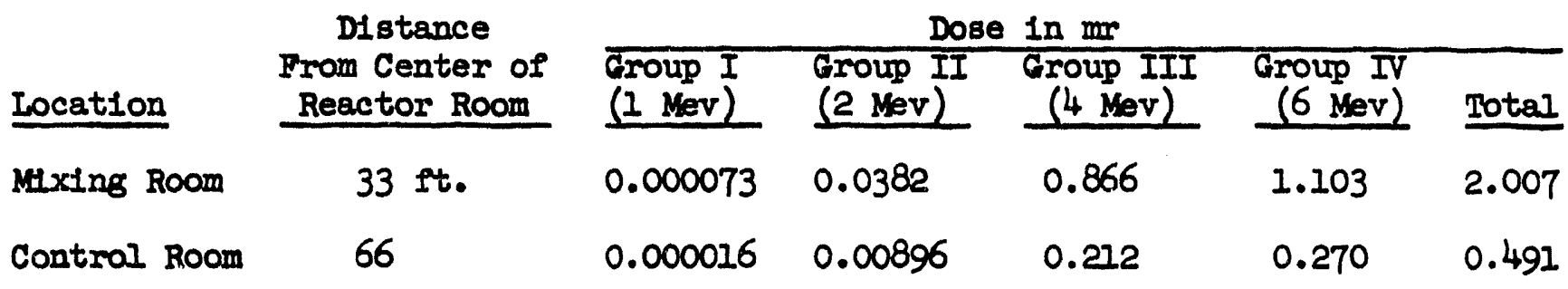

The skgrhine contributions were also calculated and are tabulated below:

\begin{tabular}{|c|c|c|c|c|c|c|}
\hline \multirow{2}{*}{ Location } & Distance & \multicolumn{5}{|c|}{ Dose in mr ( $V$ skyshine) } \\
\hline & $\begin{array}{l}\text { From Center of } \\
\text { Reactor Room }\end{array}$ & $\begin{array}{l}\text { Group I } \\
\text { (1 Nev) }\end{array}$ & $\begin{array}{l}\text { Group II } \\
\text { (2 Mev) }\end{array}$ & $\begin{array}{l}\text { Group III } \\
(4 \mathrm{Mev}) \\
\end{array}$ & $\begin{array}{l}\text { Group IV } \\
(6 \mathrm{Mev}) \\
\end{array}$ & Total \\
\hline Mixing Room & $33 \mathrm{ft.}$ & 0.237 & 0.255 & 0.307 & 0.049 & 0.848 \\
\hline \multirow[t]{4}{*}{ Contral Room } & 66 & 0.248 & 0.268 & 0.332 & 0.051 & 0.899 \\
\hline & Location & \multicolumn{5}{|c|}{ TotalrDose (mr) } \\
\hline & Mixing Room & \multicolumn{5}{|c|}{2.86} \\
\hline & Control Room & \multicolumn{5}{|c|}{1.39} \\
\hline
\end{tabular}

The neutron contribution to the total dose is less than 0.3 mrem, and hence is not presented with the foregoing. The calculations for both the neutron and gama attenuation are based upon a multiple scattering calculation, and selfshlelding by the source is neglected, thus lending a further degree of conservatiam to the results.

Criticality Studies in Support of Processing Power Reactor Fuels

A series of experiments was inftiated for the purpose of evaluating the extrapolation lengths of the water reflected heterogeneous lattices. These experiments were made with 3.063 percent enrlched uranium rods of 0.300 -inch diameter and 8 inches in length. Four of these elements placed in a lucite tube of 0.028-inch wall thickess constituted a fuel rod (32 inches in length).

Lattices of these rods in water were supported on a 3/4-inch thick aluminum plate. Four 1/2-gram RaBe sources were placed just below the aluminum plate so that sufficlent flux would be avallable to irradiate 1/4-1nch diameter, 0.005inch thick gold folls. The loadings were taken to about 94 percent of critical. Horlzontal neutron flux traverses were taken with both go? d folls and $\mathrm{BF}_{3}$ proportional counters. The flux traverse points were fltted by a least squares analysis to a $J_{0}$ function of the form $J_{0}(\alpha r)$, where $\alpha$ is the square root of the radial buckling and $x$ Is the true radial distance from the central axis of the lattlce where the flux was measured. From this fit the extrapolated radius can be calculated. The difference between the extrapolated radius and the true radius is the extrapolation length. The preliminary results of these measure- 
ments are glven as follows:

Iattice

0.700 Inch

0.800 inch
$\mathrm{H}_{2} \mathrm{O} / \mathrm{U}$ Volume Ratio

5.00

6.84
DECLSSSFFED

Extrapolation Length

Bi $_{3}$ Measurement Au Foll Measurement

$6.2 \mathrm{~cm} . \quad 6.1 \mathrm{~cm}$.

$6.5 \mathrm{~cm}$.

$6.3 \mathrm{~cm}$.

The critical masses for these 32-inch bigh loadings were also determined and measured bucklings compared with earlier calculations from 16-inch high loadings. The results are given as follows:

\begin{tabular}{|c|c|c|c|c|}
\hline $\begin{array}{l}\text { tice } \\
\text { ucing }\end{array}$ & $\begin{array}{l}\text { B20/U } \\
\text { (Volume Ratio) }\end{array}$ & $\begin{array}{c}\text { Measured } \\
\text { Crit1cal Mass } \\
\text { (32-inch } \\
\text { H1gh Cylinder) }\end{array}$ & $\begin{array}{c}\text { Measured } \\
\text { Buckling } \\
\text { (32-inch High) }\end{array}$ & $\begin{array}{l}\text { Calculated } \\
\text { Buckling } \\
\text { (I6-inch High) }\end{array}$ \\
\hline 700 & 5.00 & 355 Ibs. & $14,599 \times 10^{-6} \mathrm{~cm}^{-2}$ & $14.778 \times 10^{-6} \mathrm{~cm}$ \\
\hline 800 & 6.84 & $312 \mathrm{lbs}$. & $13,262 \times 10^{-6} \mathrm{~cm}^{-}$ & $13,383 \times 10^{-6} \mathrm{cr}$ \\
\hline
\end{tabular}

An extrapolation length of $6.5 \mathrm{~cm}$ was used in the buckling calculations.

Experiments were continued to determine reasons for the discrepancy between $k_{\infty}$ measurements Involving polyethylene $\left(\mathrm{CH}_{2}\right)$ and water moderation for 3 percent $\mathrm{U}-235$ enriched $\mathrm{UO}_{3}$-moderator mixtures having the same effective $\mathrm{H} / \mathrm{U}$ ratios. It was suspected that disagreement results elther from improper care in the handling of the water moderated samples before analysis for water content ox a possible difference in the resonance escape probability between the polyethylene and water-moderated systems at the low H/U ratios investigated.

The following experiments were performed to clear up this discrepancy.

a. A measurement of $\mathrm{k}_{\mathrm{p}}$ for a polyethylene pellet (1/8-inch diameter sphere) moderated system at a nominal $\mathrm{H} / \mathrm{U}-4$.

b. A measurement of $k_{\infty}$ for a polyethylene powder moderated system at a nominal $\mathrm{B} / \mathrm{U}-4$.

c. A measurement of $k_{\infty}$ for a water moderated system at a nominal $\mathrm{H} / \mathrm{U}=4$.

d. A measurement of the resonance escape probabllity in the polyethylene pellet and water moderated systems.

e. A measurement of $k_{\infty}$ for a water moderated system at a nominal $\mathrm{H} / \mathrm{U}=6.5$.

The first three experiments (a-c) were conducted at an $\mathrm{H} / \mathrm{U}=4$ since a large discrepancy between $\mathrm{k}_{\infty}$ measurements of polyethylene- and water-moderated systems were found in earlier experiments. The experiment at an $H / U=6.5$ was done to check a $\mathrm{k}_{\infty}$ measurement near the maximum. The $\mathrm{UO}_{3}-\mathrm{H}_{2} \mathrm{O}$ mixture was prepared by adding a known weight of water to the $\mathrm{UO}_{3}$ and mixing. Earlier mixtures were prepared by adding the $\mathrm{H}_{2} \mathrm{O}$ to the oxide by means of steam. This $\mathrm{mix}-$ 
ture is now being analyzed for water content.

Preliminary calculations indicate that the $k_{\infty}$ measurements for polyethylene and water moderated fuels are in agreement. Further analyses of these data, as well as the resonance escape probability, are beling carried out.

Criticality Calculations for Correlating Theory with Experimental Data

The study of the critical parameters for homogeneous systems of slightly enriched urantim fuel and moderator vas continued. In the Karch Monthly Report theoretical calculations of koo for sllghtly enrlched U-235 fuels and water were reported that were in good agreement with experiment. Neutron ages for these homogeneous $\mathrm{mlxtures}$ were calculated according to the following equation:

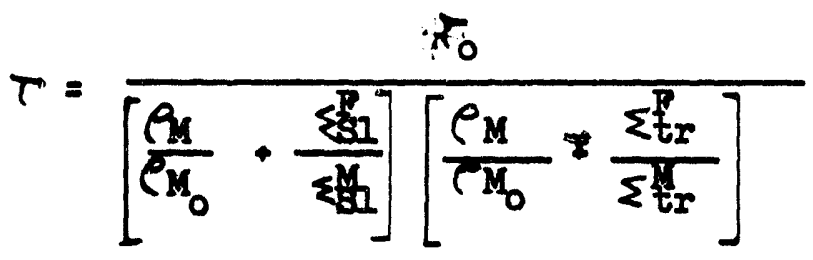

where

$$
\begin{aligned}
T_{0} & =\text { neutron age of the pure moderator } \\
T & =\text { neutron age of the system } \\
\rho_{M} & =\text { density of moderator in system } \\
\rho_{M_{0}} & =\text { density of pure moderator. }
\end{aligned}
$$

The superscripts $P$ and $M$ represent fuel and moderator, respectively, while $\Sigma_{S I}$ and $\Sigma_{t r}$ represent macroscoplc slowing down and transport cross sections, respectively. The slowing down cross section is the sum of the inelastic scattering cross section and macroscopic slowing down power. The neutron age of pure light water was taken as $27 \mathrm{~cm}^{2}$ as the use of this value for neutron age in a wide range of solution concentrations for highly enriched U-235 in light water resulted in critical mass calculations that were in good agreement with experiment.

Calculated critical parameters for homogeneous mixtures of $\mathrm{UP}_{4}$ in paraffin were made and compared with experimentel results. In these experiments the U-235 content was two percent of the total uranium. It was assumed that the neutron age of a pure moderator varled inversely as the product of the slowing down power and the transport cross section. Assuming water to have an age of $27 \mathrm{~cm}^{2}$, paraffin would have an age of $17.6 \mathrm{~cm}^{2}$. Had $32.29 \mathrm{~cm}^{2}$ been assumed as the age of water, the corresponding age for paraffin would be 21.06 $\mathrm{cm}^{2}$. This compares with $20.90 \mathrm{~cm}^{2}$ using a modified age method and an IBM 704 multigroup program. The paraffin reflected extrapolation length was calculated to be $6.38 \mathrm{~cm}$ (assuming it to be inversely proportional to the transport cross section and that for a water reflector equal to $8 \mathrm{~cm}$ ). Critical mass calculations using this method give results for paraffin reflected cylinders (diameters of 25-50 inches) that are 88-96 percent of experimental values at an $\mathrm{H} / \mathrm{U}^{235}$ 
of 195. It is not clear from the report which cylinders were paraffin reflected and which were plexiglass. Critical mass calculations for homogeneous systems at an $\mathrm{B} / \mathrm{v}^{235}$ of 294 in cylinders 25-50 inches in diameter were 106-112 percent of the experimental values if the experimental cylinders were paraffin reflected. If the experiments were conducted with plexiglass reflectors, the calculated critical masses are from 90-100 percent of experimental values.

It was not possible to make critical mass calculations for other $\mathrm{H} / \mathrm{U}$ ratios for paraffin moderated systems as the relationship between $\mathrm{H} / \mathrm{U}$ and uranium density is not avallable at this time. However, a study of homogeneous mixtures of $\mathrm{UO}_{3}$ and water (two percent U-235 content) was made and critical masses evaluated. The mintmum critical mass for water reflected systems of this material was calculated to be $5.9 \mathrm{~kg}$ U-23j. This compares with an estimated experimental mintmum critical mass for paraffin moderated and reflected systems of $4.0 \mathrm{~kg} U-235$. It is reasonable to expect that the paraffin moderated systems will have smaller minimum critical masses, because the neutron age is so much smaller in paraffin than in water.

The theory was applied to homogeneous systems of 4.9 percent U-235 enriched uraalum $\left(\mathrm{U}_{3} \mathrm{O}_{8}\right)$ in glycerol tristearate and $\mathrm{UO}_{2} \mathrm{~F}_{2}$ solutions in water. Good agreement between theory and experiment were obtained (within 5-10 percent of experimental values). It is interesting to note that for these systems the uranium concentrations were always less than $2.2 \mathrm{gm} \mathrm{U} / \mathrm{cc}$. Under these conditions the mintmum critical mass was about $2.0 \mathrm{~kg} U-235$ and the minimum critical cylinder diameter about 12 inches. Bowever, the uranium concentration of interest in processing $\mathrm{UO}_{3}$-water mixtures may be as high as $4.3 \mathrm{gm} \mathrm{U} / \mathrm{cc}$. Under these conditions the minimum critical mass is calculated to be $1.6 \mathrm{~kg} U-235$ and the minimum critical cylinder diameter is calculated to be about 10 inches.

Milscellaneous Experimenics for Nuclear Safety Specifications

1. Exponential Neasurements with 1.25 Percent Enriched Uranium

The exponential experiments with the 1.25 percent U-235 enriched $I$. and $E$. fuel elements (1.336-1nch 0.D., 0.500-1nch I.D.) were completed. The fuel rods conslsted of six elements, each 7.5 inches in length, positioned in an aluminum tube of 1.402-inch 0.D. With a 0.028-inch wall thickness. An aluminum tube filled with water was placed in the central hole for the wet core measurement. These tubes were 0.492-1nch 0.D. w1th a 0.020-1nch wall thickness. The following buckling was determined this month:

\begin{tabular}{|c|c|c|}
\hline Iattice Spacine & $\begin{array}{c}\mathrm{H} 20 / \mathrm{U} \\
\text { (By Volume) }\end{array}$ & $\begin{array}{l}\text { Buckling } \\
\text { (Puel Core Wet) }\end{array}$ \\
\hline 1.85 Inches & 1.31 & $4650 \times 10^{-6} \mathrm{~cm}$ \\
\hline
\end{tabular}

A complete report on the 1.25 percent enrlched fuel measurements is being made in the January, February, and March 1959, Nuclear Physics Research Quarterly Report, BW-60220. 


\section{Neutron Age Neasurements}

Analysis of the monoenergetic age measurement is virtually complete. Most of the effort in the past month has been devoted to estimating the accuracy of the measured ages.

Two of the numbers reported last month have been changed. The age from a small source in kerosene contained gn error in the position scale, and should read $14.15 \mathrm{~cm}^{2}$ instead of $13.98 \mathrm{~cm}^{2}$. The lower limit quoted for the age from a smali source in water has been juaged to be unrealistic. The current value for this age is $14.29 \pm 0.23 \mathrm{~cm}^{2}$.

The matrices used to determine the first-collision-approximation fits to the asymptotic flux distributions have been inverted, using an IBM 709 FORIRAN program. The inverse matrices have been used to determine the statistical precision of the asymptotic f1ts. It appears that the tails contribute about half of the overall variance in the ages. The balance of the variance comes principally from uncertainty in extrapolating to a point source. The extrapolation used is substantially larger than the largest value allowed theoretically. The final values of the age are $14.0 \pm 0.2 \mathrm{~cm}^{2}$ in water and $14.1 \pm 0.2$ $\mathrm{cm}^{2}$ in kerosene.

The thermal migration areas have been computed as $22.0 \pm 0.4 \mathrm{~cm}^{2}$ in water and $21.1 \neq 0.4 \mathrm{~cm}^{2}$ in kerosene. The former gives a diffusion length $I=2.79 \pm$ $0.07 \mathrm{~cm}$ in water. The current "best" value Prom ANL-5800 is $2.75 \pm 0.02 \mathrm{~cm}$, but the best Russian value is $2.69 \pm 0.02 \mathrm{~cm}$.

Calculation of the source spectrum is still in progress.

Vass Spectrometer for Plutonfum Analyses

Progress toward putting the mass spectrometer for this program Into operation has been confined to altering the electronic instrumentation according to the final design of the components of the other mass spectrometer. Efforts to fabricate successfully a kovar-to-glass seal for the source vacuum interlock are awalting the flring of the kovar metal according to a special firing schedule.

\section{Theoretical Critical Mass Studies}

A report, $H W-60255$, on the leakage of neutrons from subcritical plutonium solutions, has been written and is in the reproduction stage. Some of the results of this report were described qualitatively in the Monthly Report for Pebruary. In the linear time variation of reactivity problem, an analytical approximation has been made which neglects the prompt neutron lifetime. The solution of the resulting first order differential equation indicates that the effect of a geometrical buckling change accompanylng the linear change in reactivity is small for values of parameters of current interest. An analog computer formulation of this problem is also being investigated. The principal defect in an earlier numerical integration by digital computer is now attributed to an improper formulation of the problem. The acquisition of information on computational methods in critical mass problems continues. 


\section{Criticality Alarms}

The two experimental nuclear incident alarm monttors or dose-rate indicating and alarming monitors have now been tested using the two-transistor amplifier for about two months continuously with a maximum error due to drift of $2.5 \%$. All source checks (daily) have shown reading and alarm errors to be approxlmately the same (2.5\%). The instrument can be used for metering and alarm work with stable operation from one $\mathrm{mr} / \mathrm{hr}$ up to ten $\mathrm{r} / \mathrm{hr}$. The instruments are exceedingly simple and reliable.

A gam dose-rate analysis of the background in Purex is being made. The backgrounds are being checked where the nuclear Incident alarm systems will be placed.

\section{IEUTROI CROSS SECTIOI PROGRAM}

Absolute Plssion Cross Section of $0^{235}$

The study of experimental errors in the $v^{235}$ absolute fission cross section measurement has been continued. The diameter of the urantum deposited area of the $v^{235}$ flssion foll used in the experiment was redetermined using a traveling microscope. The area of the foll obtained from these measurements was $(0.85$ ₹ 0.32) percent larger than the area previously assigned from the reported size of the mask used in preparing the foll at KAPL.

Slow Neutron Scattering Cross Sections

The energy spectra of neutrons scattered from water of incident energy 0.184 ev was measured for scattering angles of 5 and 45 degrees. No experimental data have been obtained since the middle of Apr1l because of the extended reactor outage.

The observed angular distributions of elastically scattered (bound atom) neutrons for the incident energies investigated of $0.095 \mathrm{ev}, 0.141 \mathrm{ev}$, and $0.184 \mathrm{ev}$ are apparentiy the same within experimental uncertainty. This is a theoretically unanticipated effect and might be a result of the method of analysis. The effect of the finite energy resolution of the analyzer has not been taken into account and the method of subtraction of the gas scattering background has not been carefully investigated.

A PORIRAI program has been initiated to calculate the theoretically expected hard sphere gas scattering energy spectra. The results of these calculations are being used to determine to what precision the gas scattering component of the observed neutron scattering from water can be approximated by this simple model.

Subthreshold Flssion

No data have been taken on this program during the month. A sample of several milligrams of $\mathrm{Pa} 231$ was received through the courtesy of the Phillips Petroleum Company, MIR, Neutron Cross Section group, for subthreshold fission measurements. This sample joins samples already on hand of $U^{234}, U^{236}$, and $\mathrm{U}^{238}$ awaiting preparation as deposited foils for fission cross-section measurements. 
Slow Neutron Fission Cross Section - Pu241

The radiation problem which existed at 105-DR and caused the loss of at least two months operating time of the crystal spectrometer has now been ascribed to an improperly shielded test hole on the X-2 level operated by an IPD englneering group. The additional dose rate caused by the crystal spectrometer neutron beam on the $\mathrm{X}-1$ level has been determined to be well below tolerance except within a few feet of the spectrometer shlelding. No further efforts have been made to cause the spectrometer beam to be turned off with the exception of two days early in the month. Useful data were obtained on the Pu24I fission cross section about 50 percent of the nonth. The lost time was caused by spectrometer instrumentation malfunction and reactor outage.

The fission resonance at about $0.26 \mathrm{ev}$ in $\mathrm{Pu} 241$ obtained with this supposedly high yurity sample is observed to differ by as much as twenty percent in shape in the wings of the resonance from the variation deduced in earlier measurements with a sample of lower isotopic purity. The investigation of this energy region is not complete and further analysis of the data is necessary to determine if the shape difference is real.

The energy region from 1 to $20 \mathrm{ev}$ has been measured with an energy resolution about three times better than previously used in the Hanford measurements of $\mathrm{Pu}^{241}$ fission cross section but still not adequate to perform a shape analysis of resonances above about $3 \mathrm{ev}$. Slightly more structure was observed than is revealed in the latest BIL-325 cross section compliation in the region of 4 to $12 \mathrm{ev}$. In addition, two small apparent resonances were found at about $1.6 \mathrm{ev}$ and $2.4 \mathrm{ev}$. The resonance at $1.6 \mathrm{ev}$ is rather remarkably small with a peak cross section of about 10 barns.

Fast Neutron Spectra

The new model of the vernier chronotron has been tested in the laboratory and has been installed at the Van de Graaff. The testing of the resolution, sensitivity, etc. of the complete system for time-of-flight studies is in progress.

REAACTOR DEVELOPMHIT - 4000 PROGRAM

\section{PLUTOMIUM RECYCLE PROGRAM}

Correlation of Data on D20 Moderated Cluster Lattices

This work is now complete. A report is to be issued.

Low Exposure Plutonium Lattices

Pabrication of the special graphite pleces for the $101 / 2-1$ nch, $83 / 8-1$ nch, and $6 \mathrm{I} / 2$-1nch lattices is about $75 \%$ complete. It is planned to assemble these lattices in a mockup (without fuel) to guarantee compatibility of components before assembly in the PCIR.

Instrumentation designed to reduce PCIR time required to level fluxes along the longitudinal axis has been fabricated. This consists of a dual channel $\mathrm{BF}_{3}$ 
traversing device; one channel uses an enrlched $\mathrm{BF}_{3}$ tube cadmilum covered, the second channel uses a natural $\mathrm{BP}_{3}$ tube bare. They are moved simultaneously, one above the central fuel colum, the other below. Simultaneous measurements of total and epl-cadmium $\mathrm{l} / \mathrm{v}$ fluxes at a longltudinal position are made possible. The tubes are intercalibrated beforehand in the S1gma pile. This system should make possible optimum flux leveling in a strange lattice with the maximm espenditure of about one shift of PCTR time.

\section{PCTR Experiments}

Purther work on the problem of highly self-shielded Pu fuel rods has consisted of making celi calculations on clusters consisting of 0.0625 inch dia. and 0.125 inch dia. Pu rods whtch are 65-90 w/o Pu. These are not yet complete.

\section{Instrumentation}

A variable wedge was fabricated for the diameter measurement unt of the profilometer. The unit has been assembled and tested. Preliminary tests ind1cated excessive spherical aberration, lens effect, and chromatic aberration. The addition of a fllm of ofl between the spherlcal surfaces of the variable wedge to a large extent corrected all defects except chromatic aberration which has been eliminated by use of a filter. Tests of the unit with these changes indicated that diameters can be measured with a $\pm .001-1$ nch accuracy. The unit was demonstrated. A correction of a small focusing effect is still required and will be made this molth. Drawlings and a description of the printout system are belng prepared for distribution to possible vendors for cost estimation.

Calculation of thermal conductivity values for samples of graphtte and UO2 gave values in agreement with data from National Carbon Company for graphite but the values for $\mathrm{UO}_{2}$ are higher than data reported by BMI. The difference is due to the variation of thermal conductivity with temperature. A method of successive approximations which takes this variation into account is being used to calculate more correct values of $\mathrm{UO}_{2}$ thermal conductivity.

\section{GAS COOTED REACTOR PROGRAM}

\section{Lattice Parameter Measurements}

Analysis of the data obtained in the PCTR to obtain $k_{\infty}$ and $f$ is underway.

The additional fuel needed for a 16-column loading of the PCTR has been recelved and preparations are being made for the control rod experiment.

\section{Variation in Doppler Coefflclent with S/M Ratio}

Pabrication of the mockup assembly is nearly complete. Testing will begin with arrival of the Induction heater. Bids have been received on the heater, ranging from $\$ 4400$ to $\$ 7500$. No award has been made as yet.

It was found necessary to coat the stainless steel jackets of the thermocouples with molybdenum by flame spraying to prevent their failure due to forma- 
tion of an iron-uranium eutectic at elevated temperatures ( $\left.700^{\circ} \mathrm{C}\right)$.

A 12-polnt Brown recorder has been modifled to have a full scale linear span of 5 millivolts and 15 overlapping ranges, to cover the range from 0 to 60 mililivalts ( $0-1000^{\circ} \mathrm{C}$ for Iron-constantan) with an estimated accuracy of 0.0125 millivolts $\left(\sim 0.2^{\circ} \mathrm{C}\right)$.

\section{Theoretical PCTR Studies}

The small source theory critical condition for an infinite array consisting of one contral rod for each fuel rod has been found and has been related to the criticality condition for fuel rods only. The condition has been employed to predict the thermal utilization for a sample case. The result is $f=0.38$ as compared to $f=0.92$ for the same system with no control. Based on physical arguments regarding relative absorption rates in a cell, this result appears reasonable. The method is now be: ng extended to the GCR lattice which consists of one control rod for each ntne fuel rods and requires the solution of a $4 \times 4$ determinant. The elements of this determinant are now belng evaluated numerically.

\section{TEST REACTOR OPFRATIOIS}

Operation of the FCIR continued routinely during the month. There was one unscheduled shutdown due to electronic fallure. The initial experiment for the gas cooled reactor program was completed as was another series of runs to measure $k_{\infty}$ of 3 percent enriched $\mathrm{UO}_{3}-\mathrm{H}_{2} \mathrm{O}$ mixtures.

Work orders were witten for the fabrication of equipment needed for the $k_{\infty}$ measurements using 7 element clusters of 1.007 percent enrlched ursaium. As bullt drawings of the traverse device were prepared and a work order 1ssued for fabrication of a second unft. This will allow simultaneous bare and cadmilum traverses.

The reproductbility of positioning the moving face was checked by making Itve successive period measurements. After each one, the rods were dropped and the face opened one inch. The reproduclbility was within the error due to the rod drop (sta. deviation 0.007 cents).

\section{PCTR}

The prelimitary Project Proposul for the Full Scale PCTR, CGH-832, has been forwarded to Washington AEC with local Commission approval. Preliminary work on the Reactor Hazards Study has been infitiated.

\section{BIOLOGY AND MEDICINE - 6000 PROGRAM}

\section{EMVIROMMEITTAL SCIFINCES}

\section{Atmospheric Physics}

Essentially all of the $R$ and $D$ effort in this Operation was expended in the preparation and arrangement of physical equipment for the forthcoming dispersion experiments. These preparations are on or ahead of schedule. 
The erection of the towers for vertical air sampliug was approxinately 90 percent complete at month's end. The completion date for this work was scheduled for vay 8, 1959. A major injury was sustalned by a construction worker on April 22, when an 18-foot section of tower fell over as another six-foot section was being lifted into plece.

The assembly of 487 gasoline-driven vacuum pumps was completed by Transportation employees, and the testing, adjustment, and installation of this equipment at the fleld locations were begun. Two of the four automatic ploment counters were completed and accepted. New sources for the other two are being fabricated. Delivery of disposable fllter bolders and filters was assured and 14 pulse-type drum samplers were recelved from the U. S. Army Chemical Corps on a loan besis.

The visible preparations for these experiments, such as the erection of towers, assembly of prums, etc., were photographed by the Photography Operation as part of an overall documentation of the experiments. The Alr Force has dubbed this project, "Operation Greenglow," an offlcial Alr Force nickname. We have not used this designation.

\section{DOSIMEIRI}

The basic trouble with the 11ve-timer of the 256-channel analyzer in the Shielded Personnel Monitoring Station was found and corrected. Minimum maintenance was required durling the month.

Tests of the resolution obtained for the large NaI crystal with a unform array of six 3" photomultipiler tubes or five such tubes in a circle gave definitely posrer results than a circular array of six tubes. One more photomultiplier, a 10" EMI tube, remains to be tested.

Tests were made of our abllity to standardize gamma ray sources by using theoretical photofractions and efficlencles at known distances. Results were very good. The accuracy was certainly better than 5\% and usually better than $2 \%$. Tests by this method of six sources obtained on the plant uncovered errors in the values of three of them and cast aoubt on a fourth.

It was found that a box made of lead-plywood sheets such as used in X-ray shielding was quite effective in reducing the background of low energy pulses on the big NaI crystal. Many of these low energy rays result from the slowing down of higher energy gamma rays in the 1ron of the shield. The shielding was effective even though there was some small radioactivity detectable in 1t; the radioactivity could very well have been in the adhesive used to bond the lead and the plywood. It seems desirable to Iine the interior of the 1 ron room with a $1 / 8$ inch thick sheet of lead that teats show to be low in radioactivity. This has been done at other whole body counters.

The large PaI crybtal was calibrated by the one meter are method for natural body CsI37 and $\mathrm{K}^{40}$ for three subjects. The accuracy was about $20 \%$, which is sufficlent for the present. A calibration for $\mathrm{z}^{6} 65$ was obtained through the cooperation of a visitor with a known body burden of the isotope.

A subject injured in a glove box explosion was studied for plutonium contamination. Both cuts and burns were involved. Surgery had been performed prior

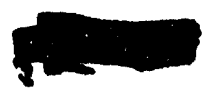


to our examination with the result that two cuts had been combined Into a single wound. There was $(1.0,0.2)$ mpe of plutontum in the wound. The exclsed flesh contained $(0.39 \neq 0.06)$ mpac. An examination of the whole side of the face and neck with a 4-1/2 Inch by $1 \mathrm{~mm}$ Nai crystal Indicated less than 2 mpe present. A second man involved in the same incldent was examined for plutonium in the lungs; none was detected.

The positive ion accelerator operated satiafactorlly during the month. The use of the new stapled belt has improved the stability of the machine. SparkIng has developed near 2 vev. It may be due to small 1ron fragments released Inside the accelerator from wearling of the staples. The X-ray warning device and interlock system were completed and put into use.

Advantage was taken of the new stablilty of the accelerator to restudy some characteristics of the $B e(d, n)$ and $D(d, n)$ reactions with the double moderator. For the latter reaction the results indicated that the angular distribution was not the same for two different targets and that the deuterium gas is probably not uniformly distributad in the titanium metal of the target.

The system for counting neutrons from radioactive sources was automated and further measurements made on plutonium oxalate, plutonfum nitrate, and several RaBe sources to obtain statistically better data.

An automatic system for gamma ray counting was put into use. $278^{24}$ in samples of effluet water was counted several times a week to calibrate the system and to test its stability. Stabllity was good.

In studies of the use of pencil ion chambers for low dose measurements it was found that electrical discharge of the chambers equivalent to 1 mr dose could be measured to better than 18 accuracy if the measurement was made immediately after discharge. If the chamber were exposed to $1 \mathrm{~m}$ of gamma radiation, however, only 5\% accuracy could be achieved. Only 5\% accuracy could be achieved with the electrical discharge method if the chambers were allowed to sit for the same length of time required for the gamma ray exposure. It is suspected that alow drifts in the charging voltage cause the decrease in accuracy. Use of a stable 6 volt battery resulted in somewhat better accuracy.

\section{IISSTRUMENTATION}

The scintillation, transistorized combined alpha-beta-gamma hand and shoe counter is still in satisfactory continuous operation in the 329 Building. The instrmment has been source-checked twice a day for almost two months with no recalibration or maintenance work found to be necessary. Personnel acceptance of the instrument has been gratifying. The instrument indicates about twice background for a $500 \mathrm{~d} / \mathrm{m} \mathrm{Pu} 239$ source distributed over a four-inch by elghtInch area, and it indicates two to three times normal background for a simflarly distributed 15 millimicrocurle Ra D-E-F source. The total Individual counting time is 15 seconds since the probes simultaneously detect the indicated types of radiation. The alpha information is separated electronically from the beta-gamma information and the two are then separately indicated.

Two final model scintillation transistorized slow and fast neutron count-rate and dose-rate meters and two final model scintillation transistorized alpha-

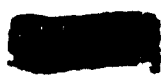


beta-ganma meters have been completed and tested sat1sfactorily. The neutron portable meter replaces, in one instrument, both the old $\mathrm{BP}_{3}$ meters and the "Neuts." The alpha-beta-gamma meters, in one instrument, replaces the old scintillation alpha "popples" and the standard GM's. In all cases, the performance of the new instruments is superior to the old types.

The composite transistor clrcuft board tester for all of our varlous plug-in type, modular construction transistor clrcuits has been completed and tested satisfactorily. This testing derlce will enable any technlclan to check the plug-in boards in a go, no-go type test. All of the transistor circuits for portable and flxed Instruments whlch we have developed can be tested. Several new stable transistor oscillators of varlous pulse repetition rates were developed and tested. These will be used to drlve the other circults being checked in the transistor tester. The transistor plug-in clrcuits that can be tested include amplifiers, multivibrators, binaries, count-rate meters, and register-driving types.

The pinhole camera was evaluated thls month. The best results were obtained by using Eastman-type kk X-ray $117 m$ for the radiation picture and Royal Pan (ASA 200) f1lm for the dayl1ght plcture. An exposure of $300 \mathrm{mr}$ from a point source at the face of the camera was necessary to produce sat1sfactory results. The camera was demonstrated by placing a $\mathrm{CO}^{60}$ bug inside of an a'uminum tube and photognaphs made. After the 11 Im had been processed, the radiation $111 \mathrm{~m}$ was lald on top of the photograph to locate the source. An attempt to Improve the sensitivity by inserting a terphenyl crystal in the film hcider and laying Royal Pan (ASA 800) on the crystal was not successful.

The Radiotelemetry Central Station equipment has row beer tested and is ready for delivery to and installation at the 622 (Meteorology) Building. RCA engineers are changing recelving and transmitting antenne pcsitions of equipment on Rattlesnake Mountain to attempt alleviation of interference problems. The Aerovane wind direction detector at the Yakima. Barricade has mined 1ts bearings and wlll be replaced, in total, by the manufacturer. Some trouble has been experlenced with the Benton City data station from cattie damaging the unft. The AEC is engaged in a study of methods to alleviate the conditior.

The four zinc sulfide paricle counters were assembled and tested this month. Two of the alpha sources recelved were not sat1sfactory because of the high background. The sources were prepared 1dentically but at different times. The reason for this background on two of the sources is unexplainable. The two units which are satisfactory have been delivered to the fleld.

An instrument for automatically counting dust particles in air has been developed. The instrument consists of a vacuum source to draw air through a pipe which is used as an impactor, a lucite disc covered with a triboluminescent pigment (pigment 3336.U. S. Radium), a photomultiplier tube, amplifier, scaler or countrate meter and a high-voltage supply. In operation, dust is impacted onto the pigment that is attached to the disc. The dust particles atriking the pigment causes 1t to scintillate. The scintillations are viewed by the phototube which changes them into electrical pulses that are amplified and recorded. Size separation can be accomplished by adjusting the space between the Impactor and the deposited pigment. 


\section{DECLLSSFFED}

The Investigation of determining the efficiencies of various light pipes continued.

Consultation was rendered to the Process Control Development Operation concernIng the use of terphenyl-in-polyvinyltaluene detectors for Pu239 alpha detection in acid-flowling process lines for Purex. The terphenyl type is to be trled as a replacement for a very thin Teflon-covered zinc-sulfide alpha detector which has not stood up to use in the acid flutd.

\section{WAGHIIOTON DESIGIALED PROGRAY}

The mass spectrometer for this program is now operated on a part-time basis (about 30 percent of available time) as an analytical service to the program. For this service the alternate ion detection system consisting of the electron multiplier, vibrating reed electrometer, and Brown recorder is beling used. The remainder of the time is being used to study experimental effects of importance to the types of samples encountered in this program and toward putting the lon counting detection system into rellable operation.

\section{CUSTOARR WORK}

Analog Computing

The problem load for the Analog Computer is buflaing up to the point where a considerable back-log has accumulated. The problems waiting for machine time are (1) Hazards re-runs for PRLR, (2) Prequency response for PRIR, (3) Primary loop frequency response for INR, (4) Pump cosst down for IRR, (5; Beat exchanger frequency response for IPR, (6) Primary loop plus heat exchanger for INR, (7) Bollout curves for exdsting reactors, (8) Bollout with the effect of meltdown of lithium polson, (9) Flux distribution with various pile loeding effects, and (10) Iog simulator for reactor kinetics (theoretical physics).

The coodyear computer has been in operation almost steadily for the last month wlth a gradual loss in capecity due to loose connectlons, bad potentiometers, etc. It is estimated that the couputer will have to go down for an overhaul before some of the larger of the above-mentioned problems can go on.

The new replacement coefficlent potentiometers have been recelved and twentyfour have been installed. The remalning thirty-81x will be installed during Nay.

Replacements for the intercept potentlometers on the diode function generators have been ordered. May 15 is the tentative delivery date.

Work has been started on the design of a better slope switch-potentiameter combination for the diode function generators and the components have been placed on order.

The order for the new computer was placed on Aprtl 20, 1959, w1th Beckman Instruments, Inc. The delivery date is six months, which would meen october 20 before the new computer arrives.

The new Brush 8-Channel Recorder has been received. All necessary wirlng bas been completed and the recorder is now in service. The Sanborn recorder is to 
be removed from service and completely overhauled at the earliest cpportunity.

A study 1s being made into the feasibllity of elther bullding or purchasing a Magnet1c Tape Type Transport Iag Simulator. Several vendors have been contacted and more w1ll be contacted in the next couple of weeks.

A one-hour talk, followed by a demonstration and discussion perlod, was given to the Design groups in CEO on Nay 4. The talk covered the basis of analog computers and thelr applications.

The IIPR Primary Ioop (Four Section Temperature Model) Frequency Respopse runs are approximately $90 \%$ complete. A few runs are st1ll to be made using a positive water temperature coefflclent.

Pump cosstdown curves for the IIPR are now beting studfed on the computer.

Report No. BN-60026, "Mult1-Region Simulation of Xenon Polsoning in the PRTR," has been Issued.

Constants necessary to make a new hazards analysis on the PRTR have been recelved.

A request for Primary Coolant Transient Analysis for the PRIR was recelved April 24. Special equipment needed for this study has delayed its solution. Four transport lag simulators are needed to soive the problem. Arrangements are being made to obtain three of these from the Ios Angeles Computer Center for a 30-day loan.

Curves depleting the response of a power rate meter after different power level ramps were recorded. The kinetics part of the problem included the constants from a natural urantum loading.

Using equations and constants from kw-32346, "Solutions of the Pile Kinetic Equations When the Reactivity is a Iinear Function of Time: I," a soluticn was attempted on the analog computer. The computer overloaded before prompt critical was reached and, since the interest was in the shape of the curve fust preceding prompt critical, a new approach seemed necessary. The log simulator which plots the 108 of the power level versus time has been programmed and is awalting computer time.

\section{Weather Forecasting and Meteorology Service}

The first Columbia RIver crest forecast was 1ssued on Apr11 21, 1959. Expected crest helghts are nearly equivalent to or slightly in excess of those observed in 1958. The forecasts for the 100 Areas and Richland are as follows (these forecasts will be amended as later information becomes avallable):

\begin{tabular}{|c|c|c|c|c|}
\hline \multicolumn{5}{|c|}{ Peak Stage (Feet above MSL) } \\
\hline & $100-B$ & $100-D$ & $100-F$ & Richland \\
\hline 1959 Forecast & $405.5-408.5$ & $394.0-397.0$ & $381.0-384.0$ & $348.5-352.5$ \\
\hline 1958 observed & 406.2 & 395.0 & 381.8 & 349.2 \\
\hline
\end{tabular}


The River is expected to crest in late May or early June, but probably before the 1938-1952 average crest date of June 7 .

\section{Type of Porecast}

8-Hour Production 24-Hour General Spectal
Number Made

90
60

60
136 of Rellability

88.4

82.1

87.5

April was the windiest month in more than 14 years of record at the Hanford Meteorology Station. The average speed of $11.1 \mathrm{mph}$ compares w1th $10.7 \mathrm{mph}$ in June of 1949, which previoubly was the windiest month of record.

Instrumentation

A count-rate system is being developed for checking the thickness of the zirconium cladding around the uranium fuel element for FPD. The probe is a scint1liation type employed terphenyl in polyvinyltoluene for beta-gamma detection. The crystal, light pipe, and shield are being fabricated for evaluation.

A complete, fair-cost estimate was prepared concerning the alpha-only scintillation transistorized hand counter. The estimate was necessary because offsite fabrication bids are belng obtalned for the fabrication of twelve of the units. The falr-cost estimate, excluding the profit factor, was found to be $\$ 2,300$ each in lots of one only. In lots of twelve required, the estimate would be reduced by about $10 \%$ per unit.

Design and fabrication work was started for conversion of the vertical lead pig beta-ganma sheif counters from mica-window GM tube use to a scintillation detector using a phototube and terphenyl in polyvinyltoluene. The very fragile mica-window tubes which cost about $\$ 200$ for replacement will then be eliminated.

A radiation warning device design was completed for Pacilities Engineering Operation, Bllo. The instrument is to monitor above a water-filled tank containing 15,000 curies of Cobalt 60. The instrument has a minimum alarm sensitivity of five mr/hr, and the alarm polnt may be varled to $100 \mathrm{mr} / \mathrm{inr}$ or greater. The detector is a two-insh by one-inch NI(MI) crystal with a 6655A multiplier phototube. The alarm circult is activated by a meter relay which measures the multiplier phototube anode current.

Acceptance tests were continued on elght Victoreen remote area monitoring systems with a total of 65 channels and a Riggs (one channel) remote area monitor. Acceptance tests were completed on 47 BAPO $\mathrm{GM}^{\prime} \mathrm{s}$.

Optical

Work was completed on the modifled Slit Camera for 105-C Fuel Inspection Facility. The camera has been delivered and the customer is instaling and testing the camera at 105-C.

Design drawings have been completed for a remotely operated TV scanning system to be used in the six-inch diameter access holes on the rear shield wall of the reactors. Fabrication of the unit is about $80 \%$ complete. 
The routine Opticel shop Work during this period includes 400 manhours work of which 35-3/4\% was for Spare Parts (Stores), 19-1/2\% was for IPD, 15\% for CPD and 29-3/4\% for HLO. During the month, 0. K. Selle left to work in Technical Shops. Work performed Included:

1. Completion of perts for FRIR profilometer components.

2. Palishing three lead glass bricks.

3. Pabrication of 20 glass bearings.

4. Pabrication of parts for TV scanner.

5. Service to 327 Butliding microscopes.

6. Fabrication of a second scratch depth microscope.

7. Evaporation plating of gold on wire loops.

8. Fabrication of a lamp projection and photocell detector mounting for R. C. Clark.

9. Fabrication of a pyroceram bearing.

PF Gast:mes

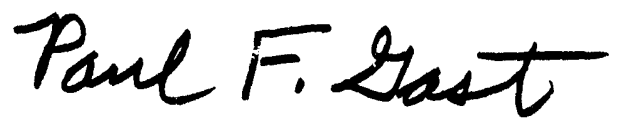

Manager

Physics and Instrument Research and Development

HAITFORD GABORATORIES OPERATION 


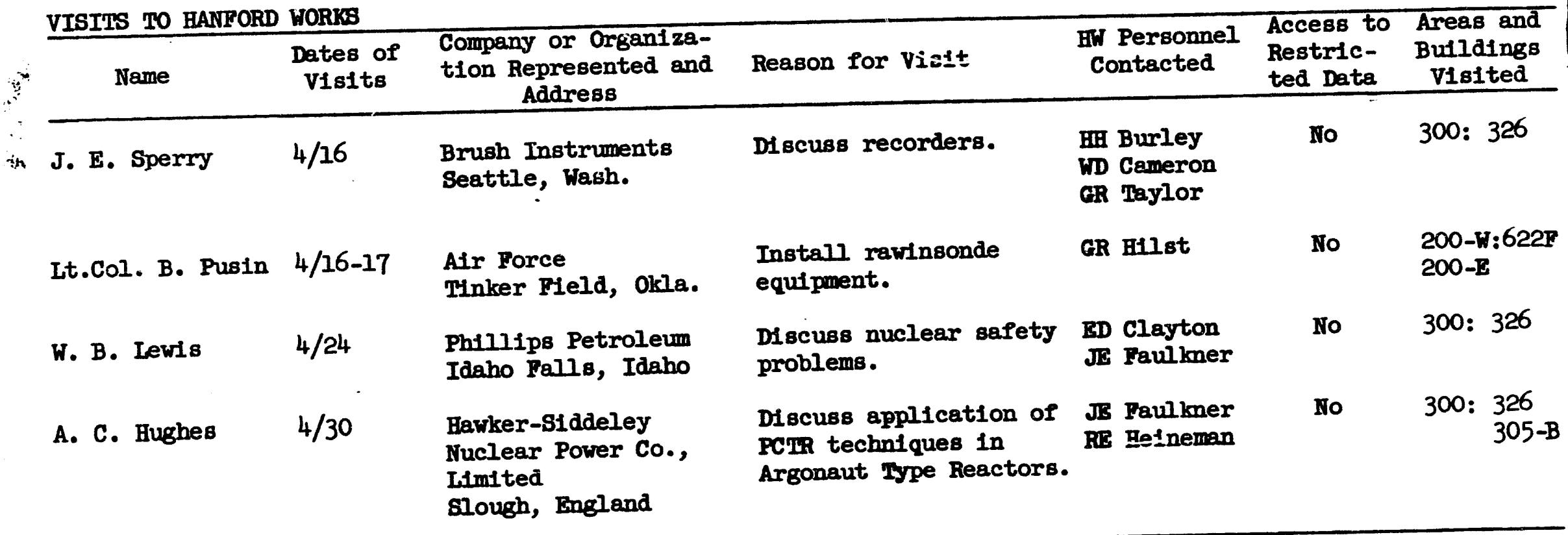

\section{VISITS TO OTHER INSTALTATIONS}

\begin{tabular}{|c|c|c|c|c|c|}
\hline Name & $\begin{array}{l}\text { Dates of } \\
\text { Visits }\end{array}$ & $\begin{array}{l}\text { Company Visited } \\
\text { and Address }\end{array}$ & Reason for Visit & $\begin{array}{l}\text { Personnel } \\
\text { Contacted }\end{array}$ & $\begin{array}{l}\text { Access to } \\
\text { Restricted Data }\end{array}$ \\
\hline C. R. Lagergren & $4 / 1-2$ & $\begin{array}{l}\text { Oak Ridge Nat'l Lab. } \\
\text { Oaik Ridge, Tenn. }\end{array}$ & $\begin{array}{l}\text { Kass spectrometer - } \\
\text { consulting. }\end{array}$ & A. E. Cameron & Yes \\
\hline A. I. Ruiz & $4 / 7-2$ & Schenectady, N. Y. & $\begin{array}{l}\text { Attend Symposium on } \\
\text { Reliability. }\end{array}$ & -- & No \\
\hline W. C. Roesch & $4 / 2-3$ & $\begin{array}{l}\text { Univ. of Washington } \\
\text { Seattle, Wash. }\end{array}$ & $\begin{array}{l}\text { To teach AEC Fellowship } \\
\text { Class. }\end{array}$ & $\begin{array}{l}\text { Paculty and } \\
\text { Students. }\end{array}$ & No \\
\hline N. Ketzlach & $4 / 5-9$ & $\begin{array}{l}\text { Nuclear Congress } \\
\text { Cleveland, Ohio }\end{array}$ & $\begin{array}{l}\text { Present a paper at } \\
\text { Nuclear Congress. }\end{array}$ & -- & No \\
\hline
\end{tabular}


VISITS TO OTHER INSTATTAMIONS

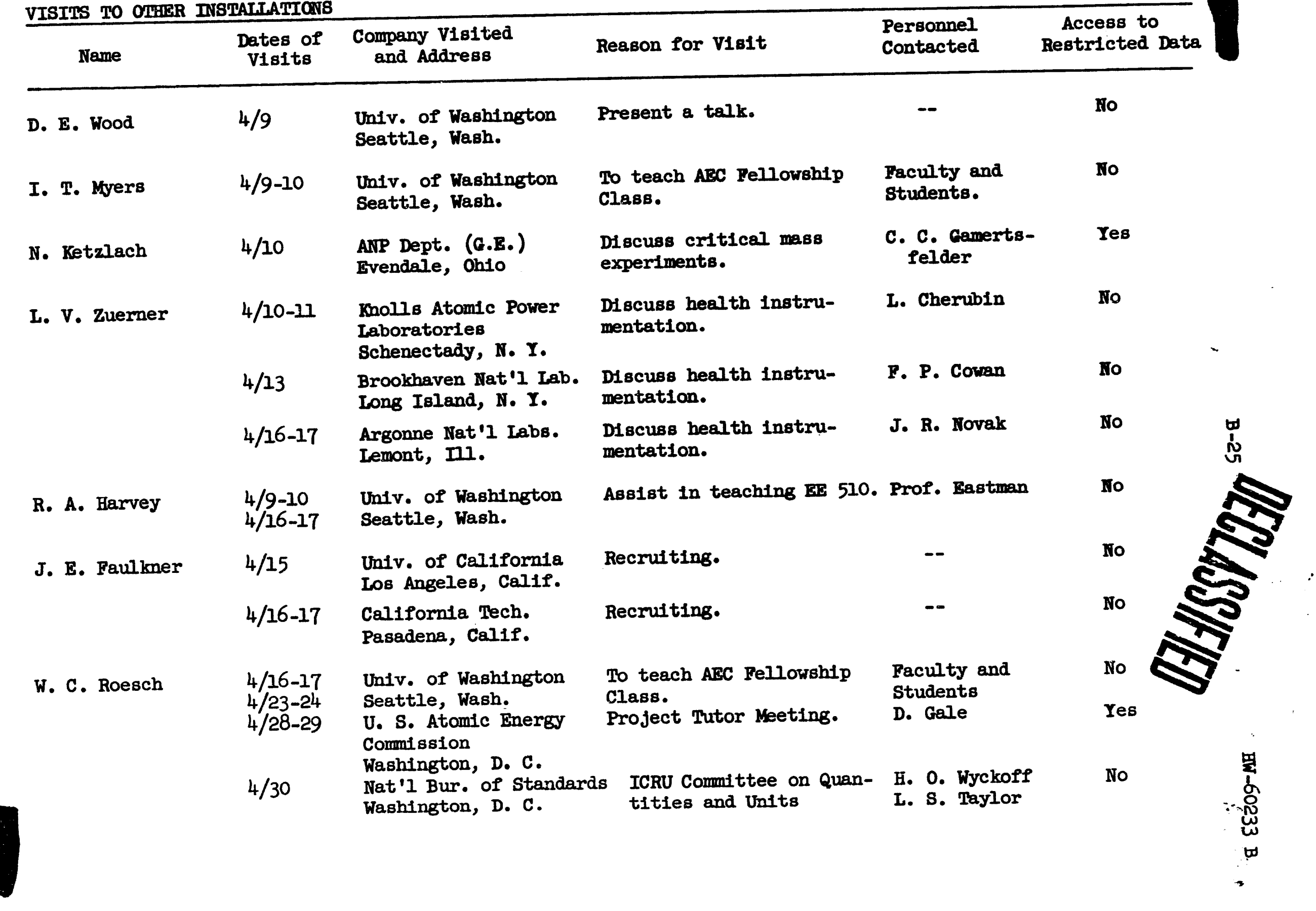




\begin{tabular}{|c|c|c|c|c|c|}
\hline Name & $\begin{array}{l}\text { Dates of } \\
\text { Visits }\end{array}$ & $\begin{array}{l}\text { Company Visited } \\
\text { and Address }\end{array}$ & Reason for Visit & $\begin{array}{l}\text { Personnel } \\
\text { Contacted }\end{array}$ & $\begin{array}{c}\text { Access to } \\
\text { Restricted Data }\end{array}$ \\
\hline P. F. Gast & $4 / 20-21$ & $\begin{array}{l}\text { Univ. of California } \\
\text { Berkeley, Calif. }\end{array}$ & Recruiting. & $-\infty$ & No \\
\hline & $4 / 22$ & $\begin{array}{l}\text { Stanford Univ. } \\
\text { Palo Alto, Calif. }\end{array}$ & Recruiting. & -- & No \\
\hline & $4 / 23$ & $\begin{array}{l}\text { G-E Vallecitos Lab. } \\
\text { Pleasantor, Calif. }\end{array}$ & $\begin{array}{l}\text { Discuss business of Stan- } \\
\text { dards Comittee } N 6 .\end{array}$ & W. J. Ozeroff & No \\
\hline R. A. Harvey & $4 / 20-24$ & $\begin{array}{l}\text { Chaik River } \\
\text { Ontario, Canada }\end{array}$ & $\begin{array}{l}\text { Attend Sixth Tripartite } \\
\text { Instrumentation Con- } \\
\text { ference. }\end{array}$ & Conf. Nembers & Yes \\
\hline R. C. $\mathrm{MaCa} 11$ & $4 / 29-30$ & $\begin{array}{l}\text { Am. Physical Soilety } \\
\text { Washington, D. C. }\end{array}$ & Attend meeting. & $-\infty$ & No \\
\hline C. R. Lagergren & $4 / 29$ & $\begin{array}{l}\text { Knolls Atomic Power } \\
\text { Lab. } \\
\text { Schenectady, N. Y. }\end{array}$ & $\begin{array}{l}\text { Consulting on Wash. } \\
\text { Designated Program. }\end{array}$ & T. L. Collins & Ies \\
\hline & $\$ / 30$ & $\begin{array}{l}\text { Am. Physical Society } \\
\text { Washington, D. C. }\end{array}$ & Attend APS meeting. & -- & No \\
\hline $\begin{array}{l}\text { D. G. Foster } \\
\text { E. D. Clayton }\end{array}$ & $4 / 30$ & Am. Physical Society & Attend APS meeting. & $-\infty$ & No \\
\hline I. T. Myers & $4 / 30$ & $\begin{array}{l}\text { Univ. of Washington } \\
\text { Seattle, Wash. }\end{array}$ & $\begin{array}{l}\text { Teach AEC Fellowship } \\
\text { Class. }\end{array}$ & $\begin{array}{l}\text { Paculty and } \\
\text { Students }\end{array}$ & No \\
\hline & & & . & & \\
\hline
\end{tabular}



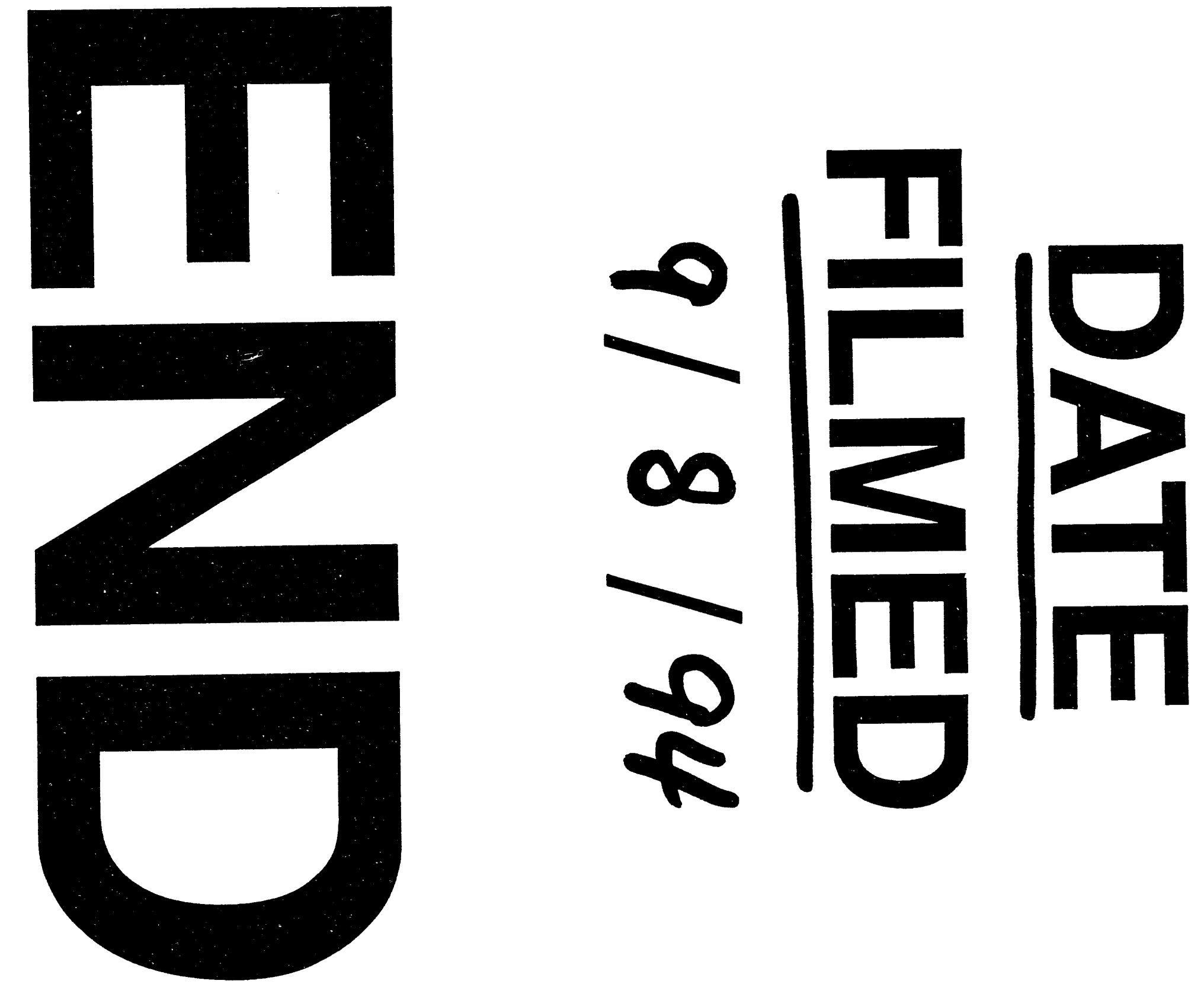
尺ㅇ

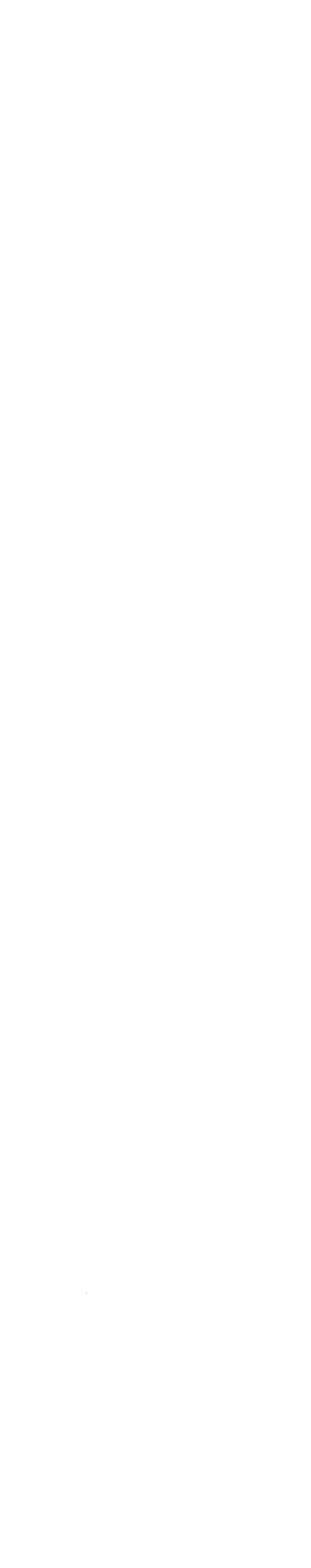




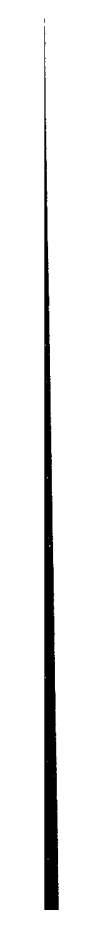

